Abstracta Iranica Abstracta Iranica

Revue bibliographique pour le domaine irano-aryen

Volume 34-35-36 | 2017

Comptes rendus des publications de 2011-2013

\title{
Roberta Menegazzi, Vito Messina. Tell 'Umar, il tempio addossato al teatro. Le fasi architettoniche e le figurine in terracotta
}

\section{Rémy Boucharlat}

\section{(2) OpenEdition \\ Journals}

Édition électronique

URL : http://journals.openedition.org/abstractairanica/41499

DOI : 10.4000/abstractairanica.41499

ISSN : 1961-960X

Éditeur :

CNRS (UMR 7528 Mondes iraniens et indiens), Éditions de l'IFRI

\section{Référence électronique}

Rémy Boucharlat, «Roberta Menegazzi, Vito Messina. Tell 'Umar, il tempio addossato al teatro. Le fasi architettoniche e le figurine in terracotta », Abstracta Iranica [En ligne], Volume 34-35-36 | 2017, document 5, mis en ligne le 15 juillet 2016, consulté le 01 octobre 2020. URL : http://journals.openedition.org/ abstractairanica/41499; DOI : https://doi.org/10.4000/abstractairanica.41499

Ce document a été généré automatiquement le 1 octobre 2020.

Tous droits réservés 


\title{
Roberta Menegazzi, Vito Messina. Tell 'Umar, il tempio addossato al teatro. Le fasi architettoniche e le figurine in terracotta
}

\author{
Rémy Boucharlat
}

\section{RÉFÉRENCE}

Roberta Menegazzi, Vito Messina. « Tell ‘Umar, il tempio addossato al teatro. Le fasi architettoniche e le figurine in terracotta », in : C. Lippolis, S. de Martino, (eds.), Un impaziente desiderio di scorrere il mondo. Studi in onore di Antonio Invernizziper il suo settantesimo compleanno. Firenze, 2011, p. 123-138. (Monografie di Mesopotamia, XIV)

1 Les disciples du récipiendaire de ces Mélanges s'attachent à poursuivre l'œuvre de celui-ci en publiant peu à peu l'énorme masse documentaire des quinze ans de fouilles italiennes sur le site de l'ancienne Séleucie du Tigre. Ici, les AA. décrivent le contexte architectural, un temple à cour adossé au théâtre plusieurs fois remanié que V.M. a par ailleurs publié ( $c f$. V. Messina, Seleucia al Tigri, 2010, Abs. Ir. 32-33, n 186) d'une série de figurines de terre cuite. Une partie seulement était en position stratigraphique, les autres provenant de la couche d'abandon. Ensemble, ces figurines de type grec, confirment que l'édifice était un temple, dédié à une divinité inconnue, mais en rapport avec la fertilité et la guérison. 


\section{AUTEURS}

RÉMY BOUCHARLAT

CNRS, Lyon 